\title{
Selecting Parental Lines among Genotypes of Capsicum annuum for Hybridization Aiming at Dry Fruit Yield Improvement
}

\author{
Majjiga Sreenivas $^{1}$, Amit Baran Sharangi ${ }^{1}$, Swadesh Banerjee ${ }^{2}$, \\ Praveen Kumar Maurya $^{2}$, Tridip Bhattacharjee ${ }^{2}$ and Arup Chattopadhyay ${ }^{2 *}$
}

${ }^{1}$ Department of Plantation, Spices, Medicinal and Aromatic Crops, Faculty of Horticulture, Bidhan Chandra Krishi Viswavidyalaya, Nadia, Mohanpur 741252, West Bengal, India

${ }^{2}$ Department of Vegetable Science, Faculty of Horticulture, Bidhan Chandra Krishi

Viswavidyalaya, Nadia, Mohanpur 741252, West Bengal, India

*Corresponding author

\section{Keywords \\ Chilli, Correlation, Genetic variability, Multivariate analysis, Path analysis, Dry fruit yield}

\section{Article Info}

Accepted:

15 April 2019

Available Online:

10 May 2019

\section{A B S T R A C T}

Increased productivity of dry chilli with appreciable fruit quality is the present need in major growing areas to promote export from our country. The present investigation was undertaken to identify important selection indices, and to analyze the genetic divergence of collected germplasm for identification of diverse parents for spice chilli hybridization program. Different components of genetic variability for 15 growth and yield component traits were determined employing 45 genotypes evaluated in autumn-winter season of 2015-16 in Randomized Block Design with three replications. High GCV and PCV values were recorded for all the characters except days to 50\% flowering, days to ripe fruit maturity from anthesis and 1000 seed weight. The proportion of genetic contribution to the overall phenotypic expression of most of the traits was very high. Both heritability and genetic advance was high for all the characters under study except days to ripe fruit maturity from anthesis, revealing additive genetic control of characters. Selection would be most useful for the improvement of these traits. Dry fruit yield/plant was found positively and significantly correlated with all the traits except days to $50 \%$ flowering and days to ripe fruit maturity from anthesis. Path coefficient analysis indicated that the maximum direct effect on dry fruit yield/plant was through ripe fruit yield/plant followed by dry fruit weight. From the combing study of correlation and path coefficient, the characters, namely ripe fruit yield/plant and dry fruit weight were the most important selection criteria, emphasis should be given on such traits while imposing selection for amenability in dry fruit yield of chilli. Based on the determination of divergence all the genotypes were grouped into 7 clusters. However, random grouping pattern of genotypes was observed indicating that geographical diversity and genetic divergence were unrelated. The intra- and inter-cluster distance among the genotypes depicted that crossing between the genotypes belonging in Cluster I and VII or Cluster III and VII will be expected to give high heterotic response in $F_{1}$ generation. The character fruit length contributed the maximum towards genetic divergence followed by fruit diameter, fruits/plant and plant spread $(\mathrm{N}-\mathrm{S})$. Based on $\mathrm{D}^{2}$ Statistics, PCA and mean performance, six genitors Beldanga, BCCH Sel-4, G-4, BCC-30, BCC-25, and Srinagar possessed the optimum combination of all variables and were identified as most promising donor parents in dry chilli hybridization programme with a view to develop promising hybrids/improved lines. 


\section{Introduction}

Chilli (Capsicum annuum L.), one of the most important vegetable cum spice crops, belongs to Solanaceae family. Twenty-five distinct species are available in the genus Capsicum (Baral and Bosland, 2002). All the Capsicum species consist of $2 \mathrm{n}=24$ chromosome number (Moscone et al., 1996). Five domesticated species namely $C$. annuum, $C$. frutescens, $C$. chinense, $C$. baccatum and $C$. pubescens (Pickersgill, 1997) are mainly cultivated in different parts of the world. Out of this Capsicum annuum is the most widely cultivated species worldwide. It is the most economic and food additive to improve food acceptability. India is one of the premier chilli growing country in the world and it is extensively grown throughout the country both under rainfed and irrigated conditions. Chilli covers an area of 0.83 million hectares with annual production of 1.872 million tonnes (Anonymous, 2017) in India. Andhra Pradesh, Karnataka, Maharashtra, Orissa, Rajasthan, Tamil Nadu and Madhya Pradesh are the leading chilli growing states in our country.

Chilli is emerging as one of the commercial spice crops at the global trade and is probably second most important vegetable after tomato. Chilli is an indispensable spice, due to its pungency, taste, appealing colour and flavour. In the international spice trade, chilli comes just after the black pepper (Piper nigrum L.) in India. In India, it is an important ingredient in daily use and is also used in the preparation of pickles, chutneys, sauces etc. Fruit is rich in vitamin A, E, C and P (Hosmani, 1993). A crystalline, acrid, volatile alkaloid, capsaicin present in placenta and pericarp is responsible for chilli pungency. Capsaicin has high diverse prophylactic and therapeutic uses in Allopathic and Ayurvedic medicine value (Sumathy and Mathew, 1984). Oleoresin is semi-solid extracts composed of a resin in solution in an essential and/or fatty oil, extracted from chilli fruits used in processed food and beverage industries and got high export potential. Naturally occurring oleoresins has also good medicinal value mainly used in pain balms. Colour extraction from chilli is also finding increased value to replace the artificial colours in the food items especially in developed countries.

The country is still lagging behind to attain the optimum productivity in dry chilli owing to use of local unimproved cultivars and heavy infestations of insect-pest and diseases particularly viral disease. Therefore much concentrated efforts are necessary to improve its dry fruit yield, quality and host plant resistance against viral diseases. Hence, evaluation of the potentialities of the indigenous germplasm is essential because promise for further improvement programme depends on the genetic diversity of the crop. Selection from the available variations is the oldest and most effective breeding procedure. The nature and extent of genetic variability is one of the most important criteria in formulating an efficient breeding programme and knowledge of phenotypic coefficient of variation (PCV) and genotypic coefficient of variation $(\mathrm{GCV})$ is much helpful in predicting the amount of variation present in a given assemblage of genotypes. In genetic studies, characters with high genotypic coefficient of variation indicate the potential for an effective selection (Sadiq et al., 1986). However, with the help of genotypic coefficient of variations alone; the heritable variation cannot be measured (Singh and Nandapuri, 1974). Genetic variability along with heritability should be considered for assessing the maximum and accurate effect of selection (Burton, 1952). Thus estimation of heritable variability and its genetic components such as genotypic coefficient of variation, genetic advance is essential in planning and execution of a breeding programme for improvement of 
quantitative attributes. Range in magnitude for the concerned character is the simplest way of expressing genetic variability for that character in the population under study. Estimation of genotypic and phenotype correlation among various characters may provide information necessary in a breeding programme when selection is based on two or more characters simultaneously. Selection of one trait results in correlated response in several other traits. Path analysis is simply standardized partial regression co-efficient which splits the correlation coefficient into the measures of direct and indirect effects of a set of independent variables on the dependent variable.

Identification of suitable high yielding, good quality parent among genotypes of chilli is a pre-requisite for the development of high yielding recombinant line(s). Genetic diversity is the base for plant survival in nature and for improvement of the crop. To develop new and improved cultivars with desirable characteristics, which include both farmer-preferred traits (high yield potential, large seed, etc.) and breeder-preferred traits (pest and disease resistance and photosensitivity, etc.). Diversity in plant genetic resources provides opportunity for plant breeders to select superior genotypes either to be directly used as new variety or to be used as parent in hybridization programme. Diversity between the parents is crucial to realize heterosis and to obtain transgressive segregants. In this context, multivariate analysis appears to be an useful technique which serves to be a good index of genetic diversity.

Considering the lack of research done in the Gangetic plains of eastern India, the present experiment was undertaken to identify superior dry chilli producing lines and to analyze the genetic divergence of collected germplasm based on important quantitative traits and to identify diverse parents for hybridization program.

\section{Materials and Methods}

\section{Plant material and field growing}

Field experiments were carried out at "C" Block Farm of Bidhan Chandra Krishi Viswavidyalaya, Kalyani, Nadia, West Bengal under the research field of All India Coordinated Research project on Vegetable Crops, situated at $23.5{ }^{0} \mathrm{~N}$ latitude and $89{ }^{0} \mathrm{E}$ longitude at an elevation of $9.75 \mathrm{~m}$ above the mean sea level.

Forty five advanced lines/varieties/accessions of chilli collected from different parts of India constitute the plant materials for this experiment. The genotypes were grown in Randomized Block Design with three replications. The seeds of 45 genotypes were sown in nursery beds during October, 2015. Seed beds were prepared in a sandy loam soil and were $20 \mathrm{~cm}$ high and $1.0 \mathrm{~m}$ wide. Weathered cowdung manure at $4 \mathrm{~kg} / \mathrm{m}^{2}$ was mixed into the beds. Beds were drenched with chlorothalonil $(2 \mathrm{~g})+$ carbendaxim $(1 \mathrm{~g})$ to avoid damping off disease. Seeds, after treatment with Thiram ( $3 \mathrm{~g} / \mathrm{kg}$ of seed), were sown during the $1^{\text {st }}$ week of October, 2015 at a shallow depth $5 \mathrm{~cm}$ apart and covered with finely sieved well rotten leaf mold (leaves left to decompose for two year) which acts as soil improver and to prevent the soil drying out. After sowing, beds were covered with straw until germination which normally takes five to seven days and hand watered regularly up to $3^{\text {rd }}$ week of October, 2015. $200 \mu \mathrm{m}$ ultraviolet (UV)-stabilized polyethylene film supported by bamboo poles was used to cover nursery beds with open sides to protect seedlings from rain and direct sunlight. Hardening of seedlings was done by withholding water 4 days before transplanting. The experimental field was 
thoroughly prepared by repeated deep ploughing and laddering by tractor to get a fine tilth before transplanting of the seedlings. Well rotten FYM @ 15 tons/ha was applied in the field during the final land preparation. Transplanting of thirty days old seedlings to the main field was done during $1^{\text {st }}$ week of November, 2015 in the afternoon hours. Spacing of the seedlings was kept $50 \mathrm{~cm}$ in both ways in the plot and each measuring 2.5 $\mathrm{m} \times 2.5 \mathrm{~m}$ accommodating 25 plants per plot. The crop was fertilized with $120 \mathrm{~kg} \mathrm{~N}, 60 \mathrm{~kg}$ $\mathrm{P}_{2} \mathrm{O} 5$ and $60 \mathrm{~kg} \mathrm{~K}_{2} \mathrm{O} / \mathrm{ha}$. Half of total ' $\mathrm{N}$ ' and full dose of ' $\mathrm{P}$ ' and ' $\mathrm{K}$ ' was applied as basal and rest half of $\mathrm{N}$ were applies in two equal splits, first at 30 days after transplanting and the rest 25 days after first top dressing. Chilli is frequently attacked by different pest and diseases so proper plant protection measures were taken during the whole experiment against different insect-pests and diseases. Crop management practices for chilli cultivation were followed as per Chattopadhyay et al., (2007).

\section{Data recording}

Fifteen randomly plants were selected of each plot in each replication to record observations on pant height $(\mathrm{cm})$, plant spread $(\mathrm{E}-\mathrm{W})(\mathrm{cm})$, plant spread $(\mathrm{N}-\mathrm{S}) \quad(\mathrm{cm}), \quad$ primary branches/plant, days to $50 \%$ flowering, days to ripe fruit maturity from anthesis, fruit length $(\mathrm{cm})$, fruit diameter $(\mathrm{cm})$, seeds/fruit, 1000 seed weight $(\mathrm{g})$, druits/plant, ripe fruit weight $(\mathrm{g})$, dry fruit weight $(\mathrm{g})$, ripe fruit yield/plant (g) and dry fruit yield/plant (g).

\section{Statistical analyses}

Mean values of genotypes were computed for determining analysis of variance. The genotypic (GCV) and phenotypic (PCV) coefficients of variations were calculated as per Burton (1952). Heritability in broad sense and genetic advance (GA), as percent of mean, was estimated according to Hanson et al., (1956). Correlation coefficients at genotypic and phenotypic levels were calculated (Johnson et al., 1955). Path coefficient analysis was used to partition the genotypic correlation into components of direct and indirect effects as per Dewey and $\mathrm{Lu}$ (1859). The $\mathrm{D}^{2}$ statistic (Mahalanobis, 1936) was used to assess genotype genetic divergence for quantitative traits. Grouping of populations was performed by using Tocher's method as described by Rao (1952). Hierarchical cluster analysis was performed with the same genotypes to observe degree of association according to characteristics expressed in a dendrogram (Ward, 1963). Principal component analysis (PCA), to identify the factor dimension of the data, was used to summarize varietal information in a reduced number of factors for selection of the best performing genotype(s).

\section{Results and Discussion}

\section{Genetic variability and heritability}

Success of any plant breeding programme is dependent on to a very large degree on the genetic variability of the available germplasm. This investigation presents the range of variation for 15 quantitative characters. Mean sum of squares for the above mentioned characters and their significance were presented in Table 1. All these characters under study showed highly significant variation among the genotypes indicating their importance in the study of genetic variability. Significant variation in chilli genotypes was earlier reported by Rathod et al., (2002), Sreelathakumary and Rajamony (2002), Chowdhary and Samadia (2004), Chattopadhyay et al., (2011), Bhutia et al., (2015).

Estimates for the co-efficient of phenotypic and genotypic variation (PCV and GCV 
respectively), heritability in broad sense $(\mathrm{H})$, and GA as \% of mean for these characters were presented in Table 2. Close estimates of GCV and PCV were recorded for all the characters except days to ripe fruit maturity from anthesis. It implies that contribution towards final phenotypic expression of these characters mostly by genetic makeup of these varieties rather than the environmental factors. This suggested that selection could be effective on the basis of phenotypic characters alone with equal probability of success in these characters. Highest GCV value was recorded for the character ripe fruit yield/plant $(79.39 \%)$ followed by dry fruit yield/plant $(78.71 \%)$ and the lowest value was observed in days to ripe fruit maturity from anthesis (8.09). Highest PCV value was recorded for ripe fruit yield/plant $(80.25 \%)$ followed by dry fruit yield/plant $(79.59 \%)$. In the present investigation ripe fruit yield/plant, dry fruit yield/plant, plant height, plant spread (E-W), plant spread (N-S), primary branches/plant, fruit length, fruit diameter, fruits/plant, seeds/fruit, ripe fruit weight and dry fruit weight showed high GCV and PCV values. These findings were supported by Rosmaina et al., (2016), Pandiyaraj et al., (2017), Murmu et al., (2017), Yogeshkumar et al., (2018), Vaishnavi et al., (2018). Moderate GCV and PCV values were found for days to $50 \%$ flowering and 1000 seed weight indicating the potential of simple selection for the improvement of such traits. These findings were supported by Jogi et al., (2013b), Elahi et al., (2017), Meena et al., (2016), Bijalwan and Madhavi (2016). However, low GCV and PCV values were observed in days to ripe fruit maturity from anthesis indicating remote possibility of simple selection for the improvement of such trait.

High proportion of GCV to PCV is desirable in selection process because it depicts that the traits are much under the genetic control rather than the environment (Kaushik et al.,
2007). The proportion of GCV to PCV observed in this study was generally high ranged from $83.57 \%$ in days to ripe fruit maturity from anthesis to $99.68 \%$ in fruit length. All these traits under study are reliable for selection in genetic improvement of the chilli genotypes. Traits whose expressions are environmentally dependent may not be reliable descriptors for morphological characterization (Samaee et al., 2003; Pandey et al., 2008). However, in this study, the proportion of genetic contribution to the overall phenotypic expression of most of the traits was very high. Therefore, their use as important discriminatory variable for chilli classification studies seems relatively reliable.

The genetic co-efficient of variation is the measure to estimate the variability of the plant characters. However, with the help of genetic co-efficient of variation alone it is not possible to determine the amount of variation that is heritable. The heritable portion of the variation was determined out with the aid of heritability estimates. Genetic variability along with heritability should be considered for assessing the maximum and accurate effect of selection (Burton, 1952). In the present investigation very high broad sense heritability ( $85 \%$ and above) was recorded for all the characters except days to ripe fruit maturity from anthesis which confirmed the findings of Chattopadhyay et al., (2011) and Hasanuzzaman et al., (2012). Above average to high heritability estimates (60-85\%) were recorded for days to ripe fruit maturity from anthesis $(69.80 \%)$. Earlier reports of Bhagyalakshmi et al., (1990) agreed well to our findings. So, most of the characters under study showed above average to very high heritability (Table 2). The high estimates of heritability in the quantitative characters have been found to be useful from plant breeders' view point as this would enable him/her to base his selection on the phenotypic performance. 
Improvement in the mean genotypic value of the selected families over the base population is known as genetic advance under selection and it depends upon the genetic variability, index of transmissibility i.e. heritability and intensity of selection, i.e. proportion of plants selected. Very high GA as \% of mean (> 100 $\%)$ was recorded for seven characters namely, plant spread (E-W), plant spread (N-S), fruits/plant, ripe fruit weight, dry fruit weight, ripe fruit yield/plant, and dry fruit yield/plant. More than $100 \%$ GA was also reported by Chakrabarty and Islam (2017) for 10 green fruit weight, 10 dry fruit weight, fruit length, fruits/plant and fruit yield/plant. High GA as $\%$ of mean (> $20 \%$ ) was recorded for the characters plant height, primary branches/plant, days to $50 \%$ flowering, fruit length, fruit diameter, seeds/fruit, and 1000 seed weight number of seeds/fruit. High GA as \% of mean (>20\%) was also reported by Pandit and Adhikary (2014) for days to 50\% flowering, fruit length, fruit diameter, fruits/plant, fruit weight, seeds/fruit, 1000 seed weight, green fruit yield/plant. Days to ripe fruit maturity from anthesis recorded moderate GA as \% of mean (13.92 \%). Johnson et al., (1955a) had suggested that heritability estimates along with genetic gain is usually more helpful than the heritability alone in predicting the resultant effect for selecting best individuals. Therefore, these two genetic parameters must be considered together to predict the expected genetic progress possible through selection. Very high heritability coupled with very high GA as \% of mean was observed for all the characters under study except days to ripe fruit maturity from anthesis. All these characters can be regarded as most important for selection because of probable control by additive gene action (Panse, 1957), and this result was supported by finding of Bhagyalakshmi et al., (1990) and Acharyya et al., (2003). Moderate heritability with moderate GA as \% of mean observed for days to ripe fruit maturity from anthesis indicating that this character was also controlled by the additive action of polygene and would be considered for selection criteria but not as efficiently as first group of characters.

From the result of genetic variability and heritability, fruit yield/plant and other component traits except days to ripe fruit maturity from anthesis emerged as most reliable characters for selection because of their probable conditioning by the additive gene action.

\section{Character associationship}

The statistics that measures the relationship between two or more variables is known as correlation co-efficient. It measures the mutual relationship between various plant characters and determines component characters on which selection can be based for improvement in yield. The genotypic and phenotypic correlations were presented in Table 3. In general, the genotypic correlations were higher than the phenotypic ones, which indicated that the phenotypic expression of the correlation is reduced under the influence of environment, although there is a strong inherent association between the various characters. Dry fruit yield/plant was significantly and positively correlated with plant height $\left(\mathrm{r}=0.421^{* *}\right.$, significant at $1 \%$ level), plant spread $(\mathrm{E}-\mathrm{W})(\mathrm{r}=0.592 * *)$, plant spread $(\mathrm{N}-\mathrm{S}) \quad(\mathrm{r}=0.607 * *)$, primary branches/plant $(\mathrm{r}=0.661 * *)$, fruit length $(\mathrm{r}=$ $0.574 * *)$, fruit diameter $(\mathrm{r}=0.289 *$, significant at $5 \%$ level), seeds/fruit $(\mathrm{r}=$ $\left.0.426^{* *}\right), 1000$ seed weight $\left(\mathrm{r}=0.564^{* *}\right)$, fruits/plant $\left(\mathrm{r}=0.739^{* *}\right)$, ripe fruit weight $(\mathrm{r}$ $=0.607 * *)$, dry fruit weight $(\mathrm{r}=0.643 * *)$, and ripe fruit yield/plant $\left(\mathrm{r}=0.994^{* *}\right)$. These results were in conformity with the findings of Yatung et al., (2014a), Rohini and Lakshmanan (2015), Vaishnavi et al., (2017), and Shweta et al., (2018) in chilli. 
Days to ripe fruit maturity from anthesis was significantly but negatively correlated $(\mathrm{r}=$ $0.597^{* *}$ ) with dry fruit yield/plant and days to $50 \%$ flowering was negatively correlated with dry fruit yield/plant. These results corroborated with the findings of earlier researchers (Rana et al., 2015, Elahi et al., 2017, Hasan et al., 2016 and Maurya et al., 2017c) indicating that early flowering and ripe fruit maturity leads to high dry fruit yield/plant. Seeds/fruit and 1000 seed weight were most contributing characters towards increased fruit weight as they were positively and significantly correlated with fruit weight and this result was supported by Chowdhary and Samadia (2004) and Sarkar (2006). From the above result, it became evident that dry fruit yield of chilli can be increased through increase in important components like plant height, plant spread (E-W), plant spread $(\mathrm{N}$ S), primary branches/plant, fruit length, fruit diameter, seeds/fruit, 1000 seed weight, fruits/plant, ripe fruit weight, dry fruit weight, and ripe fruit yield/plant.

Phenotypic correlations of the characters were partitioned to path coefficient with a view to identify important component characters having direct effects on dry fruit yield/plant. The direct and indirect effects of different characters on dry fruit yield/plant at phenotypic level were presented in Table 3. Highest positive direct effect on dry fruit yield/plant was registered by ripe fruit yield/plant (0.971) followed by dry fruit weight (0.423) and that was supported by findings of Jose et al., (2002), Yatung et al., (2014a), Manikandan et al., (2018).This was the main cause of desirable positive association of ripe fruit yield/plant and dry fruit weight with dry fruit yield/plant. These two characters should be considered as important selection criteria for dry fruit yield improvement of chilli. Some other characters like fruits/plant, plant spread (E-W) and fruit length also showed direct positive effects on dry fruit yield/plant but the magnitude was low. Four characters viz. plant spread (N-S), days to ripe fruit maturity from anthesis, 1000 seed weight and ripe fruit weight had negative direct effects on dry fruit yield/plant. These four characters had high significant and positive correlation on dry fruit yield/plant, but their direct effects on dry fruit yield/plant were negative mainly because of high negative indirect effects via other characters. From the study of character associationship, combining correlation and path co-efficient, the characters, namely, ripe fruit yield/plant and dry fruit weight were the most important selection criteria as they showed significant positive correlation and high positive direct effects with dry fruit yield/plant. Significance of these characters as important selection indices was also suggested by DeKadwey et al., (2015) Ajith and Manju (2015) and Sharma and Sridevi (2016) and so many authors.

\section{Multivariate analysis}

Mahalanobis (1936) developed the $\mathrm{D}^{2}$ statistic model to determine the divergence among population in terms of generalized group distance. It has been widely used in Psychometry and anthropometry for classificatory purpose. Later on, it has been successfully exploited in plant breeding. Multivariate analysis is a powerful tool in qualifying the degree of divergence between biological populations (genetic distance) and to assess the relative contribution of different components to the total divergence. Although, Mahalanobis's generalized distance as a measure of genetic distance occupy a unique place in plant breeding yet, as it happens in biology, several problems under the influence of random unpredictable changes due to environment, evade the direct grip of the concept well proven is more exact fields like mathematical components. It suggests the measuring the genetic distance through multivariate analysis over environment, to fortify its reliability. 
Table.1 Analysis of variance (mean squares) for 15 characters of 45 chilli genotypes

\begin{tabular}{|c|c|c|c|c|c|c|c|c|c|c|c|c|c|c|c|c|}
\hline $\begin{array}{c}\text { Source of } \\
\text { variations }\end{array}$ & Df & PH & PSEW & PSNS & PB & DFF & DRFM & FL & FD & SPF & SW & FP & RFW & DFW & RFY & DFY \\
\hline Replication & 2 & 2.45 & 1.11 & 0.48 & 0.38 & 10.99 & 0.30 & 0.75 & 0.09 & 0.36 & 0.02 & 11.14 & 0.07 & 0.0030 & 59.51 & 2.28 \\
\hline Treatments & 44 & $1004.16^{* *}$ & $1291.04 * *$ & $1342.80 * *$ & $8.08 * *$ & $277.78 * *$ & $47.32 * *$ & $915.33 * *$ & $25.30 * *$ & $352.76 * *$ & $0.75 * *$ & $943.60 * *$ & $3.73 * *$ & $0.13 * *$ & $9065.72 * *$ & $381.15^{* * *}$ \\
\hline Error & 88 & 31.7293 & 11.0062 & 8.9421 & 0.13 & 6.97 & 5.96 & 2.00 & 0.09 & 15.61 & 0.03 & 12.49 & 0.02 & 0.0010 & 65.74 & 2.82 \\
\hline
\end{tabular}

** Significant at $1 \%$ level.

PH-Plant height, PSEW-Plant spread (E-W), PSNS-Plant spread (N-S), PB-Primary branches/plant, DFF- days to 50\%flowering, DRFM- Days to ripe fruit maturity from anthesis, FL-Fruit length, FD-Fruit diameter, SPF-Seeds/fruit, SW-1000 seed weight, FP-Fruits/plant, RFW-Ripe fruit weight, DFW- Dry fruit weight, RFY-Ripe fruit yield/plant, DFY-Dry fruit yield/plant.

Table.2 Mean, range and estimates of genetic parameters of forty five chilli genotypes

\begin{tabular}{|c|c|c|c|c|c|c|c|}
\hline Characters & Mean & Range & $\begin{array}{c}\text { GCV } \\
(\%)\end{array}$ & $\operatorname{PCV}(\%)$ & $\begin{array}{l}\text { GCV: } \\
\text { PCV }\end{array}$ & $\begin{array}{c}\text { Heritability } \\
(\%) \text { in b.s. }\end{array}$ & $\begin{array}{c}\text { Genetic advance } \\
\text { as }(\%) \text { of mean }\end{array}$ \\
\hline Plant height (cm) & 60.66 & $37.60-110.60$ & 29.68 & 31.10 & 95.43 & 91.08 & 58.35 \\
\hline Plant spread (E-W) (cm) & 41.29 & $19.20-103.40$ & 50.03 & 50.67 & 98.74 & 97.49 & 101.76 \\
\hline Plant spread (N-S) (cm) & 41.43 & $20.46-100.60$ & 50.90 & 51.41 & 99.01 & 98.03 & 103.82 \\
\hline Primary branches/plant & 5.70 & $2.66-9.58$ & 28.55 & 29.24 & 97.64 & 95.37 & 57.44 \\
\hline Days to $50 \%$ flowering & 52.2 & $34.42-72.54$ & 18.20 & 18.89 & 96.35 & 92.83 & 36.13 \\
\hline Days to ripe fruit maturity from anthesis & 45.89 & $38.24-53.47$ & 8.09 & 9.68 & 83.57 & 69.8 & 13.92 \\
\hline Fruit length (mm) & 40.10 & $13.92-95.26$ & 43.52 & 43.66 & 99.68 & 99.35 & 89.35 \\
\hline Fruit diameter (mm) & 9.03 & $5.26-15.92$ & 32.10 & 32.27 & 99.47 & 98.93 & 65.77 \\
\hline Seeds/fruit & 49.79 & $24.51-75.84$ & 21.29 & 22.72 & 93.71 & 87.81 & 41.10 \\
\hline 1000 seed weight $(\mathrm{g})$ & 4.47 & $3.97-7.36$ & 11.01 & 11.59 & 95.00 & 90.23 & 21.54 \\
\hline Fruits/plant & 32.91 & $8.54-82.45$ & 53.54 & 54.60 & 98.06 & 96.13 & 108.13 \\
\hline Ripe fruit weight (g) & 2.12 & $0.87-8.33$ & 52.41 & 52.92 & 99.04 & 98.08 & 106.92 \\
\hline Dry fruit weight (g) & 0.43 & $0.20-1.61$ & 49.26 & 49.79 & 98.94 & 97.86 & 100.38 \\
\hline Ripe fruit yield/plant (g) & 68.99 & $22.30-267.42$ & 79.39 & 80.25 & 98.93 & 97.86 & 161.77 \\
\hline Dry fruit yield/plant (g) & 14.27 & $3.88-51.70$ & 78.71 & 79.59 & 98.89 & 97.81 & 160.37 \\
\hline
\end{tabular}


Table.3 Genotypic and phenotypic correlations and direct effects of characters at phenotypic level on total yield/plant

\begin{tabular}{|c|c|c|c|}
\hline Characters & $\begin{array}{l}\text { rg with total } \\
\text { yield/plant }\end{array}$ & $\begin{array}{l}\text { rp with total } \\
\text { yield/plant }\end{array}$ & $\begin{array}{l}\text { Direct effect on total } \\
\text { yield/plant }\end{array}$ \\
\hline Plant height (cm) & 0.446 & $0.421 * *$ & 0.006 \\
\hline Plant spread (E-W) (cm) & 0.606 & $0.592 * *$ & 0.014 \\
\hline Plant spread (N-S) (cm) & 0.630 & $0.607 * *$ & -0.044 \\
\hline Primary branches/plant & 0.692 & $0.661 * *$ & 0.002 \\
\hline Days to $50 \%$ flowering & -0.207 & -0.191 & 0.005 \\
\hline Days to ripe fruit maturity from anthesis & -0.712 & $-0.597 * *$ & -0.010 \\
\hline Fruit length (mm) & 0.579 & $0.574 * *$ & 0.012 \\
\hline Fruit diameter (mm) & 0.297 & $0.289 *$ & 0.004 \\
\hline Seeds/fruit & 0.451 & $0.426 * *$ & 0.000 \\
\hline 1000 seed weight $(g)$ & 0.598 & $0.564 * *$ & -0.014 \\
\hline Fruits/plant & 0.741 & $0.739 * *$ & 0.047 \\
\hline Ripe fruit weight (g) & 0.620 & $0.607 * *$ & -0.436 \\
\hline Dry fruit weight (g) & 0.656 & $0.643 * *$ & 0.423 \\
\hline Ripe fruit yield/plant (g) & 0.995 & $0.994 * *$ & 0.971 \\
\hline
\end{tabular}


Table.4 Cluster classification of 45 genotypes of chilli

\begin{tabular}{|c|c|}
\hline $\begin{array}{l}\text { Cluster with the number of } \\
\text { genotype in parantheses }\end{array}$ & Name of the genotype with source of collection \\
\hline Cluster I (22) & $\begin{array}{l}\text { IC-537658, IC-537646, IC-336754, IC-119746, IC-537595, IC-537664, IC-338782, IC-344386, IC- } \\
\text { 344370, IC-344636, IC-342400, IC-342438, EC-628891 (NBPGR); Bobbili collection-1, Bobbili } \\
\text { collection-2 (AP); Athulya, Ujwala (KL); Arka Haritha, Arka Meghana (Karnataka); Shitari-Shitari, } \\
\text { BCC-25 (W.B.), G-4 (A.P.) }\end{array}$ \\
\hline Cluster II (6) & IC-344350, IC-342465, IC-342458, IC-119611, IC-537623 (NBPGR); BCC-30 (BCKV) \\
\hline Cluster III (6) & $\begin{array}{l}\text { Blue chilli (KL); Bobbili collection-3 (AP); BCC-1 (BCKV); Local collection, Arudsil, Banihari } \\
\text { (W.B.) }\end{array}$ \\
\hline Cluster IV (8) & $\begin{array}{l}\text { Tej Amina, Chuta Bowa, Debgiri, Chuli lanka, Beldanga (W.B.); Pahelgaon (J\&K); BCCH Sel-4 } \\
\text { (BCKV); White chilli (KL) }\end{array}$ \\
\hline Cluster V (1) & IC-572492 (NBPGR) \\
\hline Cluster VI (1) & 2016-CHI Var-1 (U.P.) \\
\hline Cluster VII (1) & Srinagar (J\&K) \\
\hline
\end{tabular}

AP=Andhra Pradesh; KL=Kerala; W.B.=West Bengal; NBPGR=National Bureau of Plant Genetic Resources; BCKV= Bidhan Chandra Krishi Viswavidyalaya; J\&K= jammu and Kashmir; U.P.= Uttar Pradesh 
Table.5 Inter and intra cluster distances of 45 genotypes of chilli

\begin{tabular}{|c|c|c|c|c|c|c|c|}
\hline Clusters & I & II & III & IV & $\mathbf{V}$ & VI & VII \\
\hline I & 93.66 & 212.81 & 406.54 & 907.55 & 387.41 & 1428.85 & 3025.51 \\
\hline II & & 103.36 & 519.36 & 669.58 & 364.86 & 812.53 & 2281.39 \\
\hline III & & & 260.63 & 772.33 & 381.70 & 1656.22 & 2637.17 \\
\hline IV & & & & 274.34 & 1060.74 & 636.19 & 1449.77 \\
\hline $\mathbf{V}$ & & & & & 0.00 & 1503.25 & 2615.34 \\
\hline VI & & & & & & 0.00 & 890.28 \\
\hline VII & & & & & & & 0.00 \\
\hline
\end{tabular}

Table.6 Cluster means of 45 genotypes of chilli

\begin{tabular}{|c|c|c|c|c|c|c|c|c|}
\hline Characters & $\begin{array}{c}\text { Cluster } \\
\text { I }\end{array}$ & Cluster II & $\begin{array}{l}\text { Cluster } \\
\text { III }\end{array}$ & $\begin{array}{c}\text { Cluster } \\
\text { IV }\end{array}$ & $\begin{array}{c}\text { Cluster } \\
\mathbf{V}\end{array}$ & $\begin{array}{c}\text { Cluster } \\
\text { VI }\end{array}$ & $\begin{array}{l}\text { Cluster } \\
\text { VII }\end{array}$ & $\begin{array}{c}\% \text { Contribution } \\
\text { towards divergence }\end{array}$ \\
\hline Plant height $(\mathrm{cm})$ & 50.75 & 51.80 & 75.64 & 83.24 & 44.40 & 59.80 & 78.58 & 0.01 \\
\hline Plant spread (E-W) (cm) & 29.86 & 29.91 & 44.64 & 76.74 & 19.20 & 55.26 & 65.38 & 0.01 \\
\hline Plant spread $(\mathrm{N}-\mathrm{S})(\mathrm{cm})$ & 29.39 & 29.61 & 44.18 & 78.39 & 20.60 & 53.98 & 73.28 & 7.88 \\
\hline Primary branches/plant & 4.79 & 5.52 & 6.74 & 7.26 & 2.66 & 7.39 & 9.36 & 0.91 \\
\hline Days to $50 \%$ flowering & 52.78 & 52.09 & 49.39 & 56.21 & 42.35 & 45.28 & 41.37 & 2.32 \\
\hline $\begin{array}{l}\text { Days to ripe fruit maturity from } \\
\text { anthesis }\end{array}$ & 47.97 & 46.32 & 43.28 & 41.97 & 50.48 & 46.58 & 39.34 & 0.01 \\
\hline Fruit length (mm) & 32.69 & 52.89 & 20.92 & 52.89 & 40.40 & 95.26 & 83.56 & 43.13 \\
\hline Fruit diameter (mm) & 7.33 & 8.66 & 13.03 & 9.45 & 15.82 & 8.26 & 15.26 & 21.82 \\
\hline Seeds/fruit & 47.85 & 47.36 & 51.09 & 51.45 & 42.00 & 75.84 & 67.44 & 1.41 \\
\hline 1000 seed weight $(\mathrm{g})$ & 4.36 & 4.36 & 4.50 & 4.43 & 4.27 & 4.80 & 7.36 & 0.01 \\
\hline Fruits/plant & 26.67 & 17.61 & 46.07 & 53.28 & 22.93 & 30.73 & 32.14 & 14.34 \\
\hline Ripe fruit weight (g) & 1.81 & 2.27 & 1.48 & 2.39 & 1.58 & 4.21 & 8.33 & 3.54 \\
\hline Dry fruit weight (g) & 0.38 & 0.43 & 0.32 & 0.49 & 0.36 & 0.82 & 1.61 & 4.04 \\
\hline Ripe fruit yield/plant (g) & 45.00 & 37.58 & 67.49 & 131.39 & 36.26 & 129.48 & 267.42 & 0.10 \\
\hline Dry fruit yield/plant (g) & 9.49 & 7.23 & 14.58 & 27.13 & 8.23 & 25.30 & 51.70 & 0.51 \\
\hline
\end{tabular}


Table.7 Results of principal component analysis (PCA) for four quantitative characters of chilli contributing to divergence

\begin{tabular}{|c|c|c|c|c|}
\hline Principal component (PC) & Eigenvalue (\%) & $\%$ Variance & \multicolumn{2}{|c|}{$\%$ Cumulative variance } \\
\hline \multicolumn{5}{|c|}{ Eigenvalues and variance accounted for $(\%)$ by PCA based on correlation matrix } \\
\hline PC1 & 632.205307 & 58.70 & \multicolumn{2}{|c|}{58.70} \\
\hline PC2 & 285.556521 & 26.51 & \multicolumn{2}{|c|}{85.22} \\
\hline PC3 & 150.823708 & 14.00 & \multicolumn{2}{|c|}{99.22} \\
\hline PC4 & 7.898841 & 0.73 & \multicolumn{2}{|c|}{99.95} \\
\hline Variables & PC1 & PC2 & PC3 & PC4 \\
\hline \multicolumn{5}{|c|}{ Factor loadings due to PCs with eigenvalues greater than 1} \\
\hline Fruit length (cm) & 0.785081 & -.043947 & -.616806 & -.034328 \\
\hline Fruit diameter (mm) & 0.028881 & -.011633 & -.016390 & 0.995086 \\
\hline Fruits/plant & 0.525226 & -.479380 & 0.702891 & -.007914 \\
\hline Plant spread (N-S) (cm) & 0.016441 & 0.043378 & -.002172 & 0.090615 \\
\hline
\end{tabular}


Figure.1 Dendogram of 45 genotypes of chilli following Ward's method

Beldanga:WB

BCC-25:BCKV

BCCH Sel-4:BCKV

2016-CHIVar-1:AIRP

BCC-30:BCKV

Pahelgaon:J\&K

G-4:WB

Whitechilli:KL

Srinagar:J\&K

Ujwala:KL

Bobbilicollection-1:AP

TejAmina:WB

Arudsil:WB

IC-537595:NBPGR

Banihari:WB

Athulya:KL

Arka Meghana:TN

Bobbilicollection-1:AP

Shitari-Shitari:WB

IC-338782:NBPGR

Chuta Bowa:WB

Chulilanka:WB

IC-537664:NBPGR

IC-344386:NBPGR

IC-537658:NBPGR

IC-537646:NBPGR

Arka Haritha:TN

IC-336754:NBPGR

IC-119746:NBPGR

IC-342400:NBPGR

IC-344636:NBPGR

IC-344370:NBPGR

EC-628891:NBPGR

IC-342438:NBPGR

IC-344350:NBPGR

IC-342465:NBPGR

IC-342458:NBPGR

IC-119611:NBPGR

IC-537623:NBPGR

Bluechilli:KL

Bobbilicollection-1:AP

Local collection:WB

IC-572492:NBPGR

Debgiri:WB

BCC-1:BCKV
Ward's Minimum Variance Dendrogram

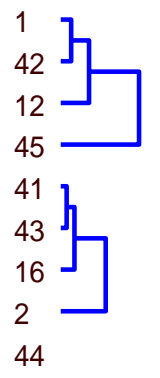

3

6 \}

17

$\left.\begin{array}{l}19 \\ 28\end{array}\right]$

5

21

7

13

37
14

${ }_{18}^{14}$

24

30

25
26

20

38

39

36

29

31

23

35

33

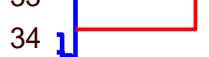

40 开

27 ]

4

8

15

22

10

11
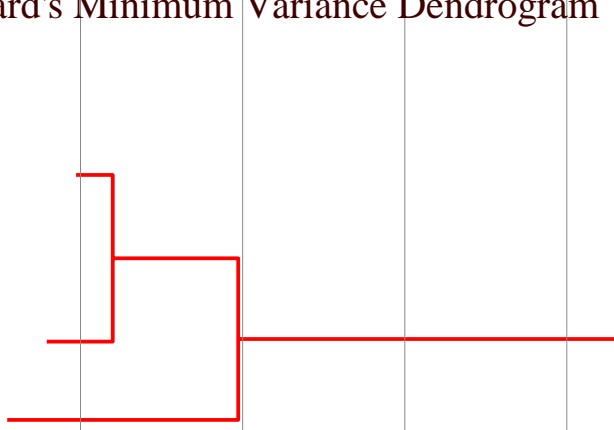
Figure.2 Scatter diagram of regression factor scores for the first and second components as determined by principal component analysis. Points in diagram closest to the intersection of 0 on the X-and Y-axes indicate similarity. Outliers on the X-axis, i.e., 1, 2, 10, 12, 16,41,42,43 and 44 indicate diversity. Numbers correspond to name of the genotype (Beldanga $=1$, White chilli $=$ 2, Debgiri $=10$, BCCH Sel-4 = 12, G-4 =16, BCC-30 = 41, BCC-25 = 42, Pahelgaon $=43$ and Srinagar $=44)$

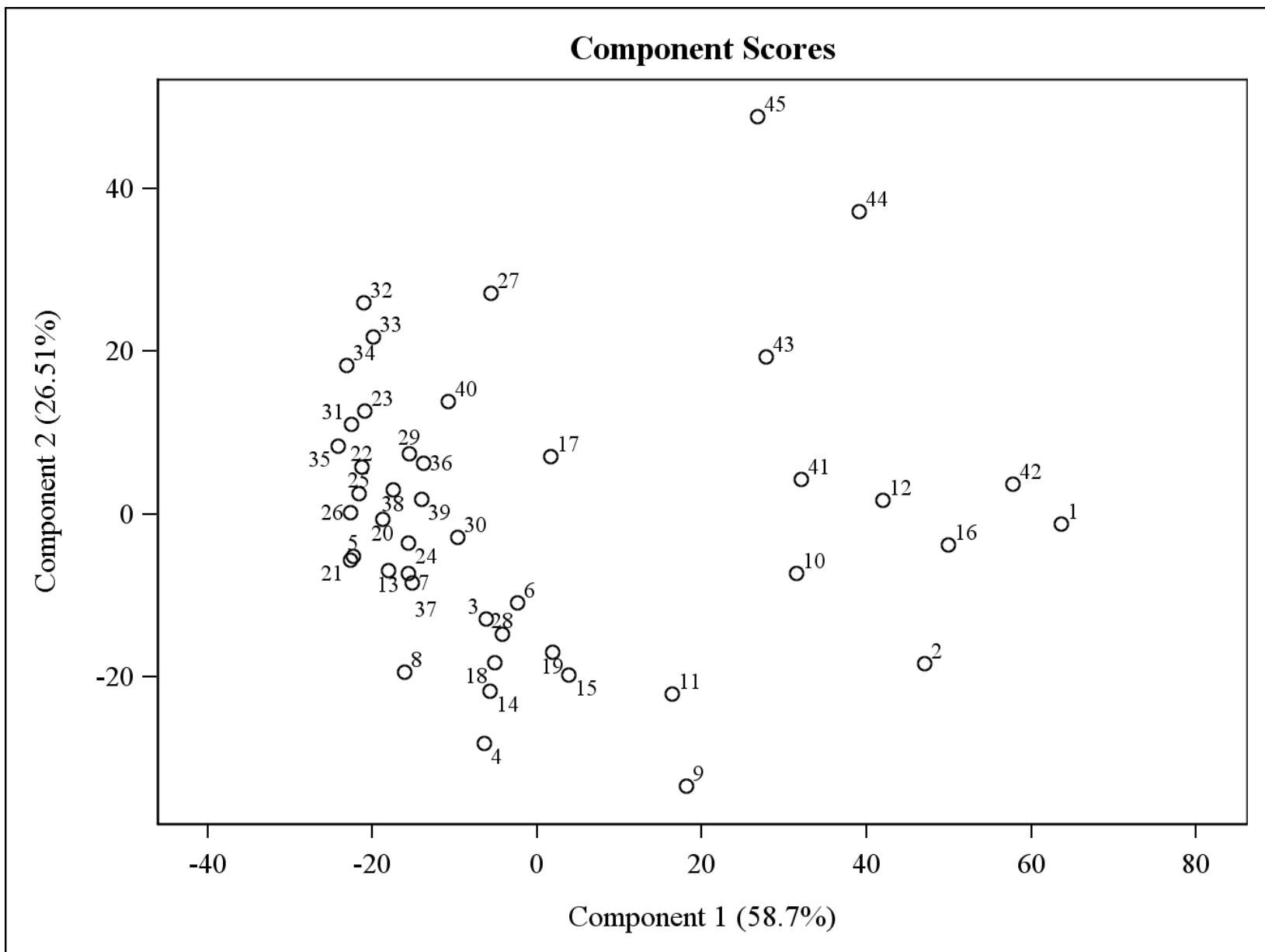


The present study aimed at analyzing the genetic divergence of 45 genotypes employing 15 important quantitative characters. Based on the degree of divergence $\left(\mathrm{D}^{2}\right.$ values) between any two genotypes a logical grouping of the genotypes with low $\mathrm{D}^{2}$ value could be arrived at by Tocher's method. Based on the determination of divergence all the 45 genotypes could meaningfully be grouped into 7 clusters (Table 4). Cluster I had the maximum of 22 genotypes followed by cluster IV with 8 genotypes, while cluster II and cluster III containing 6 genotypes in each case. Clusters V, VI and VII were monotypic in nature. Some earlier studies Shrilekha et al., (2011) also classified chilli genotypes in number of clusters while conducting experiments in different environments utilizing various genotypes. The grouping pattern of genotypes was observed to be random, indicating that geographical diversity and genetic divergence were unrelated. The absence of relationship between genetic diversity and geographical distance indicates that forces other than geographical origin such as exchange of genetic stock, genetic drift, spontaneous mutation, natural and artificial selection are responsible for genetic diversity. Therefore, selection of genotypes for hybridization should be based on genetic diversity rather than geographic divergence.

The intra- and inter-cluster distance among 45 genotypes presented in Table 5 revealed that Cluster IV showed the maximum intra-cluster value (274.34) followed by Cluster III (260.63), while Cluster I had the minimum intra-cluster value (93.66). At inter-cluster level, minimum value was observed between Cluster I and II (212.81) indicating close relationship among the genotypes included in these clusters. The maximum inter-cluster value was observed between Cluster I and VII (3025.51) followed by 2637.17 between Cluster III and VII which indicated that the genotypes included in these clusters had the maximum divergence. Hence, intermating through different crossing fashions between the genotypes included in Cluster I and VII or Cluster III and VII will be expected to give high heterotic response in $\mathrm{F}_{1}$ generation. Kalloo et al., (1980) suggested that the crosses between selected varieties from widely separated clusters were most likely to give desirable recombinants in the segregating generations.

The cluster means of 45 genotypes (Table 6) showed that the mean values of the clusters varied in magnitude for all the 15 characters. Highest plant height, plant spread (E-W), plant spread (N-S), number of primary branches/plant, fruit diameter, ripe fruit yield/plant, dry fruit yield/plant was observed in Cluster VII followed by Cluster IV. Characters like days to $50 \%$ flowering and days to ripe fruit maturity from anthesis was found early in Cluster VII. Maximum cluster mean was observed in cluster VI for fruit length, seeds/fruit, 1000 seed weight, ripe fruit weight and dry fruit weight and Cluster IV for fruits/plant. Therefore, Cluster VII could be regarded as useful sources of gene for improvement of dry fruit yield and component traits. This Cluster had taken minimum days to produce $50 \%$ flowering and ripe fruit maturity, which could be helpful for breeding an early plant type. Hence, it can be suggested from the present study that a high yielding early flowering type with desirable horticultural traits could be bred by utilizing the genotypes from Cluster VII and IV as parent in future breeding programme.

The relative contribution of individual characters towards genetic divergence was computed in terms of number of times it ranked first (Table 6). Fruit length contributed the maximum $(43.13 \%)$ towards genetic divergence followed by fruit diameter $(21.82$ $\%)$, fruits/plant (14.34\%), plant spread (N-S) 
(7.88\%), dry fruit weight $(4.04 \%)$, ripe fruit weight (3.54), days to $50 \%$ flowering $(2.32 \%)$, seeds/fruit $(1.41 \%)$ showing the possibility for selection of these characters. Similar findings were also recorded earlier for plant height, secondary branches/plant (Farhad et al., 2010); fruits/plant and fruit length (Hasan et al., 2015); fruits/plant, seeds/fruit, 1000 seed weight, oleoresin and capsaicin contents (Vanitha and Jansirani 2017); primary branches/plant, days to $50 \%$ fruiting and fruit length (Bhutia et al., 2017).

Principal component analysis (PCA) involves a mathematical procedure that transforms a number of (possibly) correlated variables into a (smaller) number of uncorrelated variables called principal components (Chatfield and Collis, 1980). The first principal component accounts for as much of the variability in the data as possible, and each succeeding component accounts for as much of the remaining variability as possible. The objectives of PCA are to discover or to reduce the dimensionality of the data set and to identify new meaningful underlying variables (Jollife, 2002). The eigenvector associated with the largest eigenvalue has the same direction as the first principal component. The eigenvector associated with the second largest eigenvalue determines the direction of the second principal component. The sum of the eigenvalues equals the trace of the square matrix and the maximum number of eigenvectors equals the number of rows (or columns) of this matrix (Harris, 2001).

PCA was performed to obtain a simplified view of the relationship between four characters [fruit length, fruit diameter, fruits/plant and plant spread (N-S)] having maximum contribution towards divergence, and variable loadings for components PC1 (fruit length), PC2 (fruit diameter), PC3 (fruits/plant) and PC4 [plant spread (N-S)] were extracted in Table 7. These components were chosen as because their eigenvalues exceeded 1.0 and explained $99.95 \%$ of the total variance. The first component (PC1) explained $58.70 \%$ of total accounted for variance in which an increase in fruit length leads to increase in fruit diameter, fruits/plant and plant spread (N-S). The second component (PC2) explained an additional $85.22 \%$ of the variance in which a decrease in fruit diameter leads to decrease in fruit length and fruits/plant and increase in plant spread (N-S). The third component (PC3) explained an additional $99.22 \%$ of the variance in which an increase in fruits/plant leads to decrease in fruit length, fruit diameter and plant spread (N-S). PCA was also analyzed to identify parents for hybridization in chilli by Farhad et al., (2010) and Hasan et al., (2014b).

High diversity occurred among chilli genotypes along with strong relationships (Fig. 1). The scattered diagram (Fig.2) clearly depicted that nine genotypes (Beldanga, White chilli, Debgiri, BCCH Sel-4, G-4, BCC-30, BCC-25, Pahelgaon and Srinagar) have registered distinct differences of their genotypic characters and belong to farthest distance from the other genotypes in the plot. Rest of the genotypes have shown similar features and formed a separate cluster.

Based on $\mathrm{D}^{2}$ Statistics, PCA and mean performance, six genitors Beldanga, $\mathrm{BCCH}$ Sel-4, G-4, BCC-30, BCC-25, and Srinagar possessed the optimum combination of all variables and these genotypes were considered for use as parents in dry chilli breeding programme to develop promising hybrids/improved lines.

In conclusion, adequate genetic component of variations has been observed among quantitative traits under study, revealing ample scope for improving the characters through direct selection. Top priority should 
be given to selection based on ripe fruit yield/plant and dry fruit weight for dry fruit yield improvement and could be considered while formulating selection indices in the improvement of spice chilli. Geographical diversity was not adequate as an index of genetic diversity. Based on multivariate analysis and average values, six genitors Beldanga, BCCH Sel-4, G-4, BCC-30, BCC25 , and Srinagar emerged as potential donors, and such information will help the breeders either to develop promising hybrids or to isolate potential lines of spice chilli from the segregating generation.

\section{References}

Acharyya, P., Rajput, C.B.S. and Acharyya, P. 2003. Variability and correlation studies for different traits in capsicum with respect to leaf curl complex. Indian J. Hortic.60 (4): 381-387.

Ajith, P. M. and Manju, P. 2015. Genetic parameters and character association for yield and anthracnose resistance in chilli (Capsicum annuum L.). Int. J. Agric. Innov. Res. 4 (1): 2319-1473.

Anonymous 2017. Horticulture Statistics, Department of Agriculture, Cooperation and Farmers' Welfare, Ministry of Agriculture and Farmers' Welfare, Government of India.

Baral, J. and Bosland, P.W. 2002. An update synthesis of the Capsicum genus. Capsicum and Eggplant Newsletter. 21: 11-21.

Bhutia, N.D., Kumar, P. and Chattopadhyay, A. 2017. Assessment of genetic diversity in chilli genotypes using multivariate analysis. Indian J. Hortic.74 (1): 135-138.

Bhutia, N.D., Setha. T., Shendeb. V.D., Dutta, S. and Chattopadhyaya, A. 2015. Estimation of heterosis, dominance effect and genetic control of fresh fruit yield, quality and leaf curl disease severity traits of chilli pepper (Capsicum annuum L.).
Sci. Hort. 182: 47-55.

Bijalwan, P. and Madhvi, N. 2016. Genetic variability, heritability and genetic advance of growth and yield components of chilli (Capsicum annuum L.) genotypes. Int. J. Sci. Res.5 (7): 13051307.

Burton, G.W. 1952. Quantitative inheritance in grass. Proceedings of the $6^{\text {th }}$ International Grassland Congress, 1: 277283.

Chakrabarty, S. and Islam, A. K. M. A. 2017. Selection criteria for improving yield in chili (Capsicum annuum L.). Adv. agric. 1-9.

Chatfield, C. and Collis, A. 1980. Introduction to Multivariate Analysis, CRC Press, Boca Raton, P. 246.

Chattopadhyay, A., Dutta, S., Bhattacharya, I., Karmakar, K., and Hazra, P. 2007. Dolichos bean, In: Technology for Vegetable Crop Production, Published by All India Coordinated Research Project on Vegetable Crops. BCKV, Nadia, West Bengal, India, pp. 218-230.

Chattopadhyay, A., Sharangi, A.B., Dai, N. and Dutta, S. 2011. Diversity of genetic resources and genetic association analyses of green and dry chillies of eastern India. Chil. J. Agric. Res. 71 (3): 350-356.

Chowdhary, B. S. and Samadia, D.K. 2004. Variability and character association in chilli land races and genotypes under arid environment. Indian J. Hortic. 61 (2): 132-136.

Dewey, D.R. and Lu, H.K. 1959. A correlation and path-coefficient analysis of components of crested wheat grass production. Agron. J. 51: 515-518.

Elahi, E., Nawab, N.N., Ramzan, A., Noor, T., Qasim, M.U., Khan, T.N. and Batool, N. 2017. Hybrid performance and analysis of genetic variability in green chillies (Capsicum annuum L.). Pak. J. Bot. 49 (6): 2221-2225.

Hanson, C.H., Robinson, H.F. and Comstock, 
R.E. 1956. Biometrical studies of yield in segregating population Korean lespedza. Agron. J. 48 (6): 268-272.

Harris, R. 2001. A Multivariate Analysis, Laurence Girlbaum Associates, New Jersey, USA, P. 624.

Hasan, H., Akand, M., Alam, N., Bashar, A. and Huque, A.K.M.M. 2016. Genetic association analysis and selection indices for yield attributing traits in available chilli (Capsicum annuum L.) genotypes. Mol. Plant Breed.7 (19): 1-9.

Hasan, M.J., Kulsum, M.U., Ullah, M.Z., Hossain, M. and Mahmud, M.E. 2014. Genetic diversity of some chili (Capsicum annuum L.) genotypes. Int. J. Agric. Res. Innov. Technol.4 (1): 32-35.

Hasan, R., Huque, A.K.M.M., Hossain, K. and Alam, N. 2015. Assessment of genetic divergence in chilli (Capsicum annuum L.) genotypes, Plant Gene and Trait, 6 (3):1-5.

Hasanuzzaman, M., Hakim, M.A., Fersdous, J., Islam, M.M. and Rahman, L. 2012. Combining ability and heritability analysis for yield and yield contributing characters in chilli (Capsicum annuum) landraces. Plant Omics J., 5 (4): 337-344.

Hosmani, M.M. 1993. Chilli crop (Capsicum annuum). Bharat Photo Offset Works, Dharwad.

Jollife, I. 2002. Principal Component Analysis. Springer Series in Statistics (2nd Edn), New York, United States of America, P. 487.

Kalloo, G., Singh, V.P., Dudi, B.S. and Partap, P.S. 1980. Analysis of variation and genetic divergence in garden peas (Pisumsativum L.). Haryana Agric. Univ. J. Res., 10: 540-46.

Mahalanobis, P. 1936. On the generalized distance in statistics. Proceedings of the National Institute of Sciences in India, 12: 49-55.

Manikandan, K., Vethamoni, P.I., Bapu, J.R.K. and Paramaguru, P. 2018.
Correlation and path coefficient analysis in $\mathrm{F}_{2}$ segregating population of chilli (Capsicum annuum L.). Int. J. Chem. Stud. 6 (2): 3620-3622.

Maurya, A.K., Kushwaha, M.L., Maurya, S.K. and Yadav Ram, P. 2017. Correlation and path analysis of yield and economic traits in chilli (Capsicum annuumL.). Indian J. Ecol. 44 (Special issue-4): 255258.

Meena, M.L., Kumar, N., Meena, J.K. and Rai, T. 2016. Genetic variability, heritability and genetic advances in chilli, Capsicum annuum. Bioscience Biotechnology Research Communications, 9 (2): 258-262.

Moscone, E.A., Lambrou, M. and Ehrendorfer, F. 1996. Fluorescent chromosome banding in the cultivated species of Capsicum (Solanaceae). Plant Syst. Evol. 202: 37-63.

Murmu, D.K., Das, B., Yanzone, R. and Barman, R. 2017. Assessment of genetic variability, character association and path coefficient of some quantitative traits of chilli. Int. J. Curr. Microbiol. App. Sci. 6 (3): 2002-2012.

Pandey, A.A., Tomer, K., Bhandari, D.C. and Pareek, S.K. 2008. Towards collection of wild relatives of crop plants in India. Genet. Resour. Crop Evol. 55: 187-202.

Pandit, M. K. and Adhikary, S. 2014. Variability and heritability estimates in some reproductive characters and yield in chilli (Capsicum annuum L.). Int. J. Plant Soil Sci., 3 (7): 845-853.

Panse, V.G. 1957. Genetics of quantitative characters in relation to plant breeding. Indian J. Genet. Pl. Br. 28: 225-229.

Pickersgill, B. 1997. Genetic resources and breeding of Capsicum spp. Euphytica. 96: 129-133.

Rao, C.R. 1952. Advanced statistical methods in biometrical research. Jhon Wiley and Sons Inc. NewYork, pp. 236-272.

Sadiq, S.M., Saleem and Igbal, J. 1986. 
Genetic variability and selection in hexaploid triticale. Proceedings of the International symposium, Australian Institute of Agricultural Science, Sydney, pp. 182-185.

Samaee, S.M., Shobbar, Z.S., Ashrafi, H., Hosseini-Mazinani, M., and Sheidai, M. 2003. Molecular characterization of olive germplasm in Iran by use of random amplified polymorphic DNA (RAPD): correlation with phenotypic studies. Acta Hortic. 623:169-175.

Sarkar, S. 2006. Studies on genetic diversity, characterization, yield components and gene action in Chilli. Ph.D. Thesis, submitted to Bidhan Chandra KrishiViswavidyalaya, West Bengal, India.

Sharma, M. and Sridevi, O. 2016. Genetic variation and character association analysis in chilli. (Capsicum annuumL.). The Bioscan.11 (3): 1675-1678.

Shrilekha, M., Raj, K.L., Mahendra, P.D., Sunian, P.S.K. 2011. Genetic variability in germplasm accessions of (Capsicum annuumL.). Amer. J. Plant Sci., 2: 629635.

Shweta, Basavarajappa, H.R., Satish, D., Jagadeesha, R.C., Hanachinmani, C.N. and Dileepkumar, A.M. 2018. Genetic correlation and path coefficient analysis in chilli (Capsicum annuum L.) genotypes for growth and yield contributing traits. $J$. Pharmacogn. Phytochem. 7 (2): 13121315.
Singh, H. and Nandpuri, K.S. 1974. Genetic variability and correlation studies in egg plant (Solanum melongena L.). J. Res. PAU. 11(2): 150-157.

Sumathy, K.M.A. and Mathew, A.G. 1984. Chilli processing. Indian Cocoa, Arecanut and Spice Journal, 7: 112-113.

Vaishnavi, B.A., Bhoomika, H.R. and Shetty, G.R. 2018. Genetic parameters study for growth, yield and quality traits in Bird's eye chilli (Capsicum frutescens L.). Int. J. Curr. Microbiol. App. Sci. 7 (5): 18131817.

Vaishnavi. B.A., Khanm, H. and Bhoomika, H.R. 2017. Correlation and path coefficient analysis in Bird's eye chilli (Capsicum frutescens L.) for yield and yield attributing traits. Int. J. Agric. Sci. Res. 7 (3): 259-266.

Vanitha and Jansiran 2017. Studies on genetic divergence in chilli (Capsicum annuит var. annuиm L.). Int. J. Agric. Sci. Res.7 (1):15-20.

Ward, J.H., 1963. Hierarchical grouping to optimize an objective function. $J$. Am. Stat. Assoc. 58: 236-244.

Yogeshkumar, H.J., Ajjappalavara, P.S., Megharaj, K.C., Patil, H.B., Revanappa, Meenakshi, S. and Gollagi, S.G. 2018. Genetic variability, heritability and genetic advance for growth, yield and quality components of ByadgiDabbi ecotypes of chilli (Capsicum annuи L.). Int. J. Chem. Stud. 6 (3): 879-881.

\section{How to cite this article:}

Majjiga Sreenivas, Amit Baran Sharangi, Swadesh Banerjee, Praveen Kumar Maurya, Tridip Bhattacharjee and Arup Chattopadhyay. 2019. Selecting Parental Lines among Genotypes of Capsicum annuum for Hybridization Aiming at Dry Fruit Yield Improvement. Int.J.Curr.Microbiol.App.Sci. 8(05): 1881-1899. doi: https://doi.org/10.20546/ijcmas.2019.805.219 